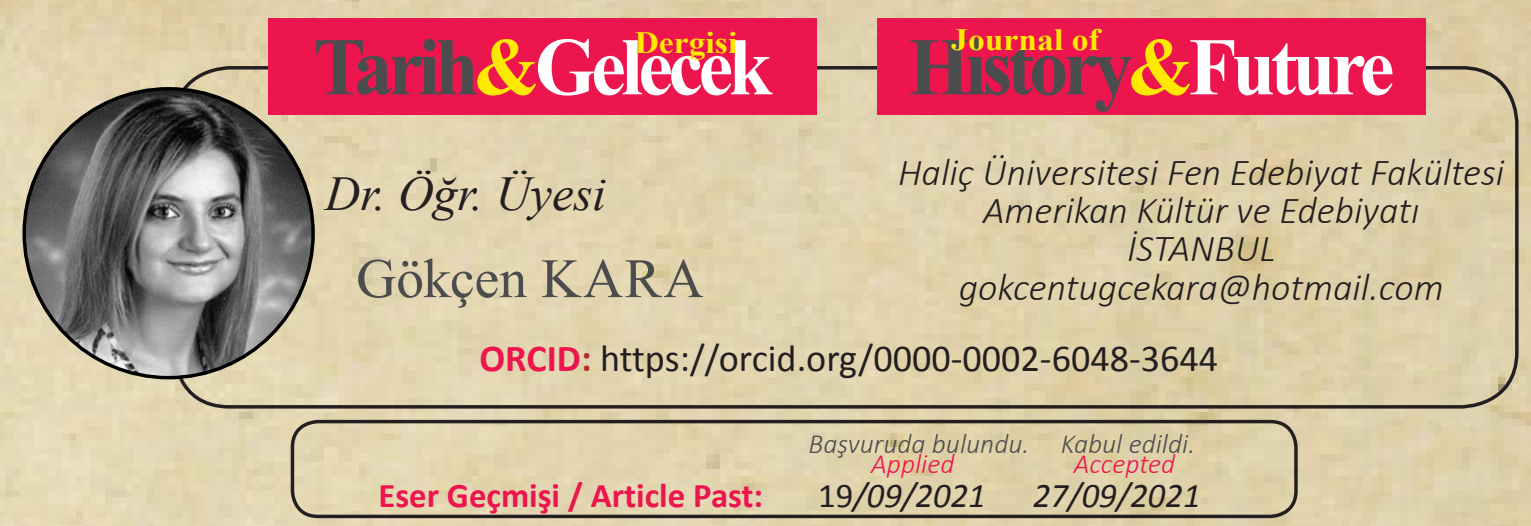

Araştırma Makalesi

DOI: http://dx.doi.org/10.21551/jhf.997644

Research Paper

Orjinal Makale / Orginal Paper

\title{
Social Identity and the Loss of Individuality in Toni Morrison's a Mercy
}

\author{
Toni Morrison'ın Merhamet Adlı Eserinde Toplumsal Kimlik Ve \\ Bireyselliğin Yitirilmesi
}

\section{ÖZ}

Bireylerin ve toplumun birbirine bağlı olması sosyal felsefenin merkezinde yer alan önemli bir konudur. Insan fizyolojik ve psikolojik olarak gruplar halinde, toplumda yaşamaya ve diğer insanlarla etkileşime girmeye uyarlanmıştır. Diğer bir deyişle insanın hem bireysel kimliği hem de toplumsal kimliği vardır. Bireysel kimlik her bir kişinin algılarına ve uyaranlarının bulunduğu ortama göre değişebilir. Başka bir deyişle, insanın bulunduğu ortama uyum sağlayabilmesi için bireysel kimliğinin sosyal kimliğinden etkilendiği söylenebilir. Aslında, sosyal kimlik veya grup kimliği, insanlar üzerinde bireysel kimlikten daha güçlü bir etkiye sahiptir. Bir insan toplumda takdir kazanmak için bireysel kimliğine uygun olmayan bazı eylemlerde bulunabilmektedir. Bireysel ve sosyal kimlik arasında önemli ilişkiler vardır. Bir grubun üyesi olarak kolektif bir kimlik geliştiren kişiler, belirli durumlar altında hareket ederken kişiliklerini değiștirebilir ve yeniden tanımlayabilirler. Bu makalenin konusu olan Toni Morrison'ın Merhamet (2008) adlı eseri, bireysel kimlik ve sosyal kimlik arasındaki çatışmayı ve bireyin karar vermesini etkileyen sosyal süreçleri ele almaktadır. Roman aynı zamanda bireyin toplum karşısındaki çaresizliğini de ele alır. Merhamet, toplumun ve sosyal etkileşimlerin, yani birey üzerindeki baskın gücün, kimlik oluşturma süreci üzerindeki etkisini ve kişinin sosyal güçler tarafından nasıl şekillendirildiğini romandaki karakterler üzerinden örneklemektedir.

Anahtar Kelimeler: Merhamet, sosyal kimlik, bireysel kimlik

\section{ABSTRACT}

A central theme of social philosophy is that man and society are interrelated. Humans are physiologically and psychologically adapted to live and interact with others in groups and in society. In other words, humans have both an individual identity and a social identity. Personal identity can change according to the perceptions and stimuli of the environment. In other words, it can be said that individual identity is influenced by social identity to adapt to the environment. In fact, social identity or group identity has a stronger influence than individual identity. A person may take some actions that do not fit his individual identity in order to be recognized in the society. There are significant interrelationships between individual identity and social identity. People who develop a collective identity as a member of a group can change 
and redefine their personality when they act in certain situations. Toni Morrison 's novel A Mercy (2008), which is the subject of this paper, deals with the conflicts between individual identity and social identity and the social processes that influence individuals' decision making. The novel is also about the helplessness of the individual in the face of society. A Mercy uses the characters in the novel to illustrate the influence of society and social interactions, i.e. a dominant power over the individual, on the process of identity formation and how one is shaped by social forces.

Key Words: A Mercy, social identity, individual identity

\section{INTRODUCTION}

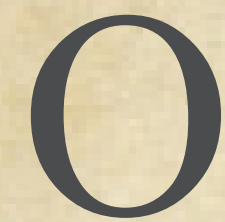

ne of the core topics of social psychology is the concept of identity. Social scientists and psychologists have developed their ideas around this concept, keeping in mind the psychosocial aspects of the formation and development of identity in social situations. According to the famous social psychologist Henry Tajfel, a person's identity can be divided into two components: 'personal identity' and 'social identity'. The concept of social identity has been developed across a wide range of theoretical frameworks and in all areas of the social and behavioral sciences.

Social identity refers to the idea that people's sense of self is based on their membership in a community. In other words, people depend on groups and have therefore developed a fundamental need to belong to social groups. Tajfel (1978: 63) claims that "the part of an individual's selfconcept that results from knowledge of his or her membership in a social group (or groups), together with the value and emotional significance attached to that membership." People are motivated to fit into certain groups and exclude others. This reflects the conflict that exists between the individuality that comes with one's identity and the urge to fit in or conform to societal norms. The criteria by which an individual views these groups as 'ingroup' and 'outgroup' varies; however, there are many social identity groups. For example, race, ethnicity, and gender. A Mercy, which is the subject of this study, shows that belonging to a group is very important in society. Morrison shows that her characters are stuck in the dilemma of what they want to do and what they should do. In other words, they behave the way society thinks they should. The characters in the novel suffer from an identity crisis as a result of oppression by society. In doing so, Morrison explores the depths of human psychology.

First of all, even though a person has a social identity that affects his behavior, that identity does not completely define him. Indeed, the person has the capacity to change and thus to shape and affect his social identity. In other words, each individual has a number of different identities that can change over time. When differences are observed, it seems "natural" to assign negative connotations to them, to associate them with the supposedly inferior or superior. According to Tajfel, people classify similar stimuli according to their similarities and opposite stimuli according to their differences. Just as they classify animals and plants by their similarities, they classify people by gender, nationality, ethnicity, and the like. Race is seen as a category that establishes and justifies systems of power, privilege, disenfranchisement, and oppression. Whites, who are the dominant group in the novel, marginalize those who are not like them and ignore their individual identities. According to social identity theory, people tend to think in terms of "us" and "them". What a person thinks of as "us" is called an "ingroup". People generally tend to glorify their ingroup because they see the ingroup as an extension of themselves. People tend to exclude, belittle and humiliate the so-called outgroup categories, as Ashforth\&Mael (1989: 20) state:

It is argued that (a) social identification is a perception of oneness with a group of persons; (b) social identification stems from the categorization of individuals, the distinctiveness and prestige of the group, the salience of outgroups, and the factors that traditionally are associated with group formation; and (c) social identification leads to activities that are congruent with the identity, support for institutions that embody the 
identity, stereotypical perceptions of self and others, and outcomes that traditionally are associated with group formation, and it reinforces the antecedents of identification. This perspective is applied to organizational socialization, role conflict, and intergroup relations.

In $A$ Mercy there are not only racial and gender groups. At the same time, we can see the social classes created by society's imposed understanding of "whoever has money is strong and valuable". The fact that the protagonist Vaark acts contrary to his understanding is due to this perception created by society. Society is considered the most important element that determines how individuals learn to think and behave. People learn their culture - the customs and traditions of society - from birth. This process is called socialization. Their culture influences how they behave, and it also influences how they perceive others. It influences their values, what they think is good and bad. This is an example of how the culture they live in influences their choices.

Culture and social groupings are inextricably linked. Culture is crucial to the formation of social identities. Belonging to a group helps people meet important psychological and social needs, such as belonging somewhere or getting the attention of others. Belonging to a group also allows people to achieve a positive social identity. Maslow (1968) placed the need for building social relationships directly above more basic drives such as satisfying hunger but below the need for respect in his hierarchy of needs. According to this, the process of building social relationships is usually associated with good feelings. Rejected people are more prone to psychological or emotional problems than people whose relational needs are satisfied.

Tajfel argues that the imposition of collective identities on marginalized groups - such as those who are less popular and have poor social status - causes their individual identities to suffer. People who belong to these groups are often undervalued and stigmatized, making them vulnerable to feelings of shame and worthlessness. Or they struggle against authority to regain their dignity. From this point of view, it is necessary to define the term "disadvantaged group". In general terms, it can be said that people who have greater difficulties in social inclusion and advancement, including ethnic minorities, migrants, the disabled and the elderly, are referred to as disadvantaged groups. Social groups give individuals a strong sense of belonging and a kind of protection in times of stress. Whether membership in a social group is chosen based on gender, skin color, or simply at random, it has a tremendous impact on human behavior - with both good and bad consequences. While social group membership can simultaneously serve to foster both positive and negative prejudice against members of other groups, it can also foster a dislike of those who violate group norms, as well as exclusion of groups that have been negatively stereotyped (e.g., women).

Social, cultural, economic and political factors have a significant impact on vulnerability, discrimination and marginalization. Thus, women belonging to these categories are often exposed to a variety of forms of discrimination as well as gender-based violence. There are few avenues for them to obtain protection, support, and redress when their rights are violated. Men have more social authority than women. This power imbalance causes men and women to engage in significantly different behaviors. In other words, because men have more power in public, they exhibit more dominant behaviors in private, and because women have less power, they tend to behave more submissively in interactions. Simply put, gender identity is only one of the several identities in a hierarchy of meaning created by society.

A Mercy reflects on the slave trade in the early 17 th. century and portrays a cast of characters: a landowner Jacob Vaark, his wife Rebekka, who had recently moved to America; Lina, a Native American whose tribe had been utterly decimated by smallpox; Florens, the unfortunate slave girl bought as payment for a bad loan; and Sorrow, the captain's young daughter, left at sea when the ship she was traveling on was destroyed in a hurricane off the coast of the Carolinas. Their voices bear the physical and psychological scars of the challenges of their lives as they tell their stories. The story transports the reader to America's revolutionary times when conflicts over race, religion, and class were on the rise. In this environment, people are forced to make difficult choices. Jacob adamantly refuses to accept a slave as payment for a financial hardship, but he believes it is the only choice he has. Furthermore, he is not interested in the slave trade because he prides himself on his honest work, but he is willing to make large profits from slave labor on the sugar plantations 
in Barbados. Florens's mother does not want to leave her daughter, but she believes that Florens will be better off with Jacob than she would be if she stayed with her own cruel owner. Rebekah realizes that even as a white woman, her only options are wife, servant, or prostitute. The three slaves, Florens, Lina, and Sorrow, are aware that they no longer have a choice when both their master and mistress die. This is a world where women of all races and ethnicities, including white, black, and Native American, are especially vulnerable and literally at the mercy of the men who exercise authority over them. Many traits are common to all female characters, although they are very different. Each of them is completely alone and powerless on her own. All of the characters in the novel exist in a linear hierarchy. All of the women belong to Jacob, who is basically in total control.

A Mercy highlights the lives of six different people from the perspective of four different narrators. Although the story is told from several perspectives, Florens' voice is the most important. Florence is the protagonist of the novel and she is the first character introduced to the reader. She takes up more space in the story than any other character. Her coming of age forms the framework of the novel. Morrison has tried to show through her the problems of the most vulnerable people in the New World. As an African slave, Florence had to deal with the pain of being displaced and unwelcome in a new land. She lost her family ties, her most precious treasure, when she moved away from home. The separation from Florence's mother permanently damaged his mental and emotional health. Her tortured self-esteem is always in search of solace. On Vaarks' plantation, she receives motherly attention from Lina, another Native American slave. But her shattered selfimage is not overcome even after the arrival of the blacksmith. Florens longs for a way to fill the void left by the loss of her childhood identity. Morrison also explores the influence of parental neglect on the formation of a person's identity. This maternal neglect is in turn a result of the system that made the slave trade necessary and exacerbated the plight of slaves.

Florens feels unloved by her mother after learning that her mother has declared that she does not want her. As a result, she experiences a difficult childhood in which she receives little care, attention, or support. According to Henry Tajfel, the way people treat others has a significant impact on how they treat themselves. The harsh criticism she receives from those around her has destroyed her sense of social identity. Florence's dissatisfaction and anxiety are exacerbated by the lack of basic concepts such as love, belonging, and attachment in her life, forcing her to search for a better existence. But no matter how hard she tries, she will never find the respect she seeks. This is because she is a minority, both as a woman and as a black woman, and minorities belong to the out group. Tajfel stated that collective identities are often imposed on minorities, especially those with low social standing and social prestige, causing these groups to experience an identity crisis. Members of these groups are often undervalued and marginalized, leading to internal difficulties in maintaining a stable identity or external disputes with authorities.

To be a woman in the seventeenth century was to be subject to an additional classification. The combination of immigrant and woman creates a very vulnerable situation. Morrison illustrates what it was like to be a woman in a culture that was too patriarchal, where religion, government, and society offered no security. It was her immigration status that established her fractured identities, and her gender status caused additional misery. Women's status is also an important indicator of social identity. The patriarchal social conditions of the time caused women to be perceived by society as the "other" and it was society that created the marginalized status of women.

The slaves in the novel were not only subject to racial discrimination, but also to the prejudice of slave status and membership in that social class. People with group identities have to explain themselves to others. Therefore, it is understandable why Morrison's characters struggle to find their own identities. The characters in the novel are practically all from a subordinate social class. Each character has his or her own vernacular and idiosyncratic thought patterns that exist beyond the imperial standard. That is, society has created a certain pattern and expects its members to be $y^{2}$ molded to that pattern. Anyone who falls outside these patterns is ostracized. 


\section{MERCY: THE POWER OF SOCIAL IDENTITY AND THE LOSS OF INDIVIDUALITY}

Morrison's works highlight the complex and diverse conditions that minorities and others with less power face in the United States. Racism, exclusion, prejudice, slavery, and identity are all themes that appear frequently in Morrison's novels. Her characters are unable to develop a sense of identification because they have suffered massive cultural trauma that makes it impossible for them to find their own identity. In their search for a rooted identity in the face of a violent and dehumanizing past, Morrison's characters can only relate to others if they are allowed to by those who control them. Morrison emphasizes the essential role that social identity plays as a functional component to a person's identity.

In a time of rapid social change, in which hierarchies of race, class, and gender increasingly hold society together, $A$ Mercy addresses the individual's quest for self-determination. Memories of the past usually get in the way of attempts to conform because past experiences get in the way. Characters often fail at this task due to traumatic memories. A Mercy encompasses both the personal and social dimensions of identity as Morrison's orphaned and transplanted characters reveal the vulnerabilities and concerns that separate them from others while connecting them to community.

Toni Morrison creatively uses the idea of human nature in the novel and gives the reader many examples. The most relates to Jacob Vaark. Vaark had believed that the slave trade was immoral, but nevertheless, he accepted a slave in return for the money that he had loaned to a slave trader from Maryland, D’Ortega. In this relationship, Morrison illustrates the fundamental materialism of man, which co-exists alongside the history of man. Vaark had been offered a slave in return for the repayment of a debt he was owed. The slave trade contradicted his moral beliefs. However, while his spiritual values were important to him, social dignity was just as important. Vaark is caught by this dilemma for a while and eventually agrees to take the slave as much because he was dazzled by Senhor D'Ortega's assets, his house in particular, as for his social dignity. Vaark had begun to wonder how he could become rich and how using the example of the slave-owner, he may become as wealthy as Senhor D'Ortega with as fine a house.

Man's identity is determined by his social status, only in this way can he continue his life. Otherwise, the individual will be wiped out by the power of society. In the novel, Florens exemplifies this situation: "I will never again unfold my limbs to rise up and bare teeth" (Morrison: 3 ). Florens has now changed. She was shaped by the events she experienced.

One of the most important indicators of the change that society imposes on people in the novel is Rebekka. She became a completely different person after her husband died. Rebekka, who was like friends with Lina, who loved Florens, who was nice to Sorrow, has now become a woman who treats everyone in the house badly. Rebekka does not allow Sorrow to stay at home. She thinks of selling Florens to another farm. Florens refers to Rebekka and calls out: "How could she not know the single friend she had?' (Morrison: 73)

Blacksmith also exemplifies this situation:

I am remembering what you tell me from long ago when Sir is not dead. You say you see slaves freer than free men. One is a lion in the skin of an ass. The other is an ass in the skin of a lion. That it is the withering inside that enslaves and opens the door for what is wild. (Morrison: 160).

As can be seen from the above section, the blacksmith who gave hope to Florens while Vaark was alive changes after Vaark died. The most important reason for this situation is that Vaark is not alive. Because Vaark meant power for Florens. When Vaark died, Florens was helpless. Florens, whose role and identity changed according to the situation, was left alone when his master died. That's why the blacksmith sees Florens helpless. 
The individual is never fully independent of society. More specifically, the individual possesses rationality but also multifaceted social values. Society inevitably affects the way people use their rationality. The concept of 'individual', which has a very important place in social science, was reconsidered by thinkers like Geertz and Foucault:

The individual is an effect of power, and at the same time, or precisely to the extent to which it is that effect, is the element of its articulation. The individual which power has constituted is at the same time its vehicle (1980: 98).

At no time in history has there been an individual who has not been influenced by his social circumstances. For this reason, the individual can be seen as an indicator of the society and time in which he finds himself. According to Foucault, the most important reason for people's changeability lies in their pursuit of "strength" and power, especially economic power. All social relations are determined by the basic relations, especially economic relations. This situation reveals people's helplessness and especially their dependence on financial power. When it comes to the ordinary economic agent, and especially when it comes to formal representation in general equilibrium models, the man is generally described as being concerned solely with his own and self-interested welfare.

One of the remarkable elements in A Mercy is that the novel displays how helpless people can be. All the characters in the novel are unhappy. First of all, Jacob Vaark was affected by the assets of Senhor D'Ortega and gave up his moral values. Although he mercifully agrees to take Florens, he knows very well that slaves are very profitable. Described as a mysterious character, Vaark is not entirely well-intentioned. Three things lead him to buy slaves. First, if he accepts a slave in return for the debt, he will not suffer financial damage. Second, if he had a slave, things could get better, and he could become richer. Third, he wanted to assist this helpless little girl. Vaark has three conflicting wishes. Although Vaark had attained the financial power he initially expected, he wanted to become richer over time. That's why the only reason people want to be masters of the future is to change their past. Although details of Vaark's previous life are not very clear in the novel, it is implied in some sections that he is not a very wealthy person. "An uncle he had never met from the side of his family that had abandoned him died and left him one hundred and twenty acres of a dormant patroonship in a climate he much preferred" (Morrison: 12). In this sentence, the source of Vaark's wealth is stated. So, the land he owned was inherited from this mysterious person, and he was not a very wealthy person either. The text later confirms this. "Now here he was, a ratty orphan become landowner, making a place out of no place, a temperate living from raw life" (Morrison: 12).

Vaark wanted to be a much richer person in the future, to forget his past. Vaark tried to change his past, but his ambition to be richer brought him down. Vaark could not fight the disease he was suffering from. Many people who had obeyed him while he was alive did not even attend his funeral. This was because they all feared that Vaark's illness would infect them. Some of those who did not attend Vaark's funeral were Willy and Scully. Although it seems interesting that neither of them attended this ceremony, the situation is actually different. Willy and Scully need each other because they are gay. When one of them dies, the other can no longer satisfy his sexual needs. In the novel, Morrison tries to explain that each person needs the other by depicting the characters as a chain ring.

The novel tells of the helplessness of the lower classes, who are generally considered forgotten. Even the strong characters in the novel are often helpless. In this work, Morrison describes the helplessness of man, regardless of his class. Man comes into the world with his helplessness. As Vaark's situation clearly shows, all people, whether members of the upper class or the lower class, have desperate aspects.

Florens, one of the most important characters in the novel, is the main indicator of human helplessness from the beginning to the end of the novel. First of all, she was born in the house of Senhor D'Ortega, who treated his slaves very badly, and she thought she was abandoned by her mother as a child. In the house of Vaark, she fell in love with the blacksmith and was unhappy all her life. "To get to you, I must leave the only home, the only people I know" (Morrison: 
5). Florens reflects her own helplessness with this sentence. On the one hand, one understands Florens' obligatory loyalty to her master, and on the other hand, her own helplessness. Florens is desperate because she has never experienced love. On one side there is the need for protection and food, on the other side there is the need to be loved. This need leads to paranoia. Florens believes that the blacksmith loves her. In other words, she is unaware or unwilling to acknowledge her social position.

The character who is in every way the opposite of Florens is Rebekah. She is luckier than any other woman in the novel. Perhaps the only thing she has in common with Florens is that both women were given to Vaark by his parents. Rebekka is not a slave, but a lady of this manor. Moreover, she is loved by Vaark. Moreover, she is respected by all the characters. But Rebekah is not happy because she has lost her children. She is in a position that many characters in this novel desire. She is both free and from the upper class. In the case of Rebekka and Florens, one can come to the following conclusion. Man is a changeable creature, not happy. Society creates his unhappiness. Rebekah would be happy if she did not have to marry, perhaps not through an arranged marriage, but through someone she liked. But society has not given her that chance. Florens might have married the blacksmith if only she had been free. But looking at all these possibilities from a different perspective, Florens might not want to marry the blacksmith if she were free. Man is a victim of his passions. Florens' desire to be loved is due to the fact that she is not loved at all. At the same time, the pursuit of her passions has once again upset Florens.

The only character in this novel who does not change is Lina. She has definitely managed to stay the same and help people with her knowledge. However, she is incapable like the other characters. She has no choice in life. She lost her family and was sexually abused by men. Man is a helpless being. He does not marry because he loves, but because he needs to marry. Humans need each other. Despite all of Vaark's wealth and dignity in society, he must find a wife to help him work at home. An interesting point in the novel is Vaark's search for a wife through an advertisement. True, Vaark could also marry Lina. But by the standards of the time, it is not normal for a free man to marry a slave. Another point mentioned in the novel is Vaark's sexual use of grief. This is the possibility because it is not made clear in the novel:

She is ever strange and Lina says she is once more with child. Father still not clear and Sorrow does not say. Will and Scully laugh and deny. Lina believes it is Sir's. Says she has her reason for thinking so. When I ask what reason she says he is a man (Morrison, 8).

If such an event has occurred, this indicates the helplessness of both Sorrow and Vaark. Vaark is helpless; because he cannot prevent his sexual needs. Sorrow is helpless; because she cannot resist the sexual abuse of men. Vaark described his wife Rebekka as 'northern light'. In this sense, the themes of 'dark' and 'light' are intertwined in the novel. Vaark's life is full of darkness. He also lost his family. He sees Rebekka as a light to get rid of his darkness. However, Rebekka cannot change her sad end.

Another dimension of desperation in the novel is portrayed between Lina and Rebekka:

It took a while for trust between them. Perhaps because both were alone without family, or because both had to please one man, or because both were hopelessly ignorant of how to run a farm, they became what was for each a companion. A pair, anyway, the result of the mute alliance that comes of sharing tasks (Morrison: 75).

The chain of need established by Morrison through these indicators is evident in all the relationships in this novel. Since a person cannot survive on his own, s/he needs others to meet his or her needs. Morrison tries to underline another truth by exposing the limits of human selfsufficiency. Man is helpless in the face of society. He has to be a part of society in order to survive.

The rules set by society are not violated in most parts of the novel. The biggest example of this situation is seen with slavery. In the novel, the slaves are doomed to remain slaves. They cannot marry, love freely, read, or write. When Vaark died, the enslaved women at home were upset because they knew they would be sold to others again. 
In the novel, marriage is first and foremost a social necessity. Social stability provided by marriage is more essential than compatibility between spouses. The story makes it quite obvious that a single man with a substantial amount of money is in need of a wife for social respect. Women also need men to survive. Men, on the other hand, have to get married in order to enhance their position in society. Jacob Vaark states that being a boss requires having a wife:

Worth every day of the long search made necessary because taking over the patroonship required a wife, and because he wanted a certain kind of mate: an unchurched woman of childbearing age, obedient but not groveling, literate but not proud, independent but nurturing. And he would accept no scold. Just as the first mate's report described her, Rebekka was ideal (Morrison: 20).

Vaark has very specific requests. In order for him to attain and maintain a respectable position, he must find a partner that fits the ideals of his society. Ths is why Vaark chooses Rebekka. Lina was considered "wild" because she bathes naked in the river every day. However, she taught Vaark how to farm, fish, and survive in a new environment. She also saves people's lives with herbal medicines. But Vaark sees no value in Lina as a bride because she does not adhere to the religious tenets of the society she is in.

People have no chance to choose their own life. The enslaved women in the novel are sexually abused by men. This is not their choice but the role that society chooses for them. These are all external factors. For example, it is the society that teaches Lina that it is a sin to swim naked in the river and to take cherries from the tree. In this work, motherhood and fatherhood are handled in a very different way. They are not depicted as instinctive or innate values; rather, they are patterns that society places in the human mind. All the women in the novel have been abandoned by their families.

Another event in the novel that draws attention is Vaark's loss of his three children. Pining for the child, he takes in Florens. However, he never treats Florens as his own child. Since instincts are directed by society, Vaark can allow Florens to learn to read and write, raise her well, and give her freedom, but he is bound by society's barriers. A slave must remain a slave, that is his fate. The same is true of Sorrow. Sorrow is not a slave. She has been taken into this house. But she is being used as a slave. Although Vaark is considered a good person, it is society that determines the good and the bad. The societal values are the factors that determine Vaark's personality. The themes of good and evil are multidimensional in the novel. Morrison tries to show that a person cannot simply be good or bad. Society shapes a person's character. Social determinism, which is the process in which society shapes people, is also shown in the novel in love.

The love of Rebekka and Jacob Vaark is based on social values. Rebekka came from a family that does not value women. The cultural conditions in which Rebeka grew up considered male sovereignty as appropriate. As she was raised with traditional values, she believes in the superiority of the man. Rebekka fulfills all the requests of Jacob, making him happy, which also makes her happy. According to her, her biggest responsibility in her life is to make her husband happy and to serve him. After all, they seem to be in love with each other, whereas there is no love. There are people shaped by social pressures.

The love between Lina and Florens represents another love motif in the novel. Florens sees Lina as her mother. The relationship between them turns into a mother-child relationship. Nevertheless, social pressures are also obvious in this relationship. Both women are desperate. They are in search of love. They have no choice but to love each other. Maybe if the conditions were different, Lina would not have liked Florens so much. Another interesting point in the novel is that Rebekka, as a woman who lost her children and felt a sense of motherhood, treats Florens and Sorrow as slaves while she should love them more. Instead, being the lady of the house requires establishing authority. From this point on, it can be said that even the most basic instincts, such as motherhood instinct, are formed by social values.

Willard and Scully also fall in love with each other. The same-sex love that develops between them is not very clear in the novel. This situation is due to the social authority of the time. At that time, homosexuals were considered guilty, meaning homosexuality was not acceptable. The most noticeable love in the novel is the unrequited love between Florens and the blacksmith, who is not 
named in the novel. The blacksmith never accepts Florens because she is a slave. Society does not allow a free person to marry a slave. Moreover, the blacksmith is a wealthy person while Florens is a slave without shoes. Because of society's constructs, love will always be unrequited in this novel.

An individual is a unique human being who possesses a distinctive identity defined by his desire to become who he wishes to be. Social identity is only one component of that person's personal identity. Possessing one social identity does not prevent an individual from adopting another. To do so, he must be able to reflect on whether his social and cultural background or place within society is best suited to his own aspirations.

\section{CONCLUSION}

People develop their identities by defining themselves in terms of their group memberships and affiliations, and they also act in certain ways as part of their acceptance of the group's standards. In this approach, an individual's function is submerged within the notion of the group. A Mercy describes the process of identity development in an oppressive social environment. The novel explores the effects of racism and sexism on a society that has been enslaved, and shows the process of personal and social identity construction under the white-dominated system. Morrison shows that her characters are stuck in the dilemma of what they want to do and what they should do. In other words, they behave the way society thinks they should. The characters in the novel suffer an identity crisis as a result of oppression by society. In doing so, Morrison explores the depths of human psychology.

A Mercy deals with the politics of social structure and focuses on how social norms can affect the personalities of the characters. Morrison, enlists marginalized voices to reveal the loss of individuality in the community. Her characters are so bound by societal judgments that they have lost their own individuality. Morrison has also incorporated overt allusions to race, gender, and economic inequality that emphasize an ideology of white privilege. The narrative structure of the novel does not prioritize one voice over another. Morrison describes her characters' journey from personal to social identity. People are unable to discover their true identities because institutions bind them to society's ideals rather than their own.

\section{REFERENCES}

Ashforth, B. E., \& Mael, F. (1989). Social Identity Theory and the Organization. http://www. jstor.org/stable/10.2307/258189?refreqid=search-gateway.

Foucault, M. (1980). Power / Knowledge: Selected Interviews. New York, The Harvester Press.

Hall, S., \& Du Gay, P. (Eds.). (1996). Questions of Cultural Identity. London, Sage Publications.

Morrison, T. (2017). A Mercy, New York, Vintage International.

Tajfel, H. (1966). Co-operation Between Human Groups. The Eugenics Review, 58, 77-84.

Worchel, S. (2011). Social Identity: International Perspectives. London, Sage Publications. 